\title{
Investigation Into Pre-service English Teachers' Beliefs on Teaching Grammar
}

\author{
Xuechen $\mathrm{Hu}^{1}$ and Yingliang Liu ${ }^{1, *}$

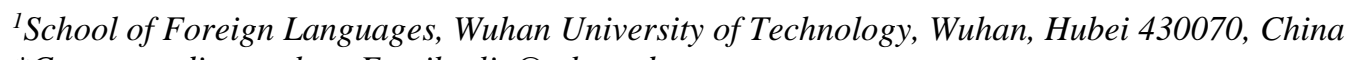 \\ *Corresponding author.Email: yliu@whut.edu.cn
}

\begin{abstract}
Teachers' beliefs, especially on teaching grammar, play an indispensable role in language teaching. Grammar provides people with the necessary structure to organize their ideas effectively and appropriately. This paper aims at identifying pre-service English teachers' beliefs on teaching grammar instruction as well as factors that influence their beliefs. Instruments employed in the survey include questionnaires and in-depth interviews. This study shows that pre-service teachers have affirmative beliefs towards grammar teaching in some aspects. Many factors influence their beliefs, including external factors as well as internal factors.
\end{abstract} Keywords: Pre-service Teacher, English Teaching, Grammar Instruction, Beliefs

\section{INTRODUCTION}

In language learning and teaching, it is assumed that pre-service teachers need the knowledge taught in core courses such as linguistics and second language acquisition in order to become effective and competent practitioners [1]. How to integrate their beliefs on teaching grammar instruction into foreign language classrooms is of prime importance. However, grammar teaching itself has always been a controversial issue. According to Busch [1], teachers' beliefs are influenced by their background as language learners.

The discussion has, for the most part, concentrated on the different approaches to grammar instruction. The purpose of this study is twofold. Firstly, it aims to explore the beliefs of pre-service teachers regarding teaching grammar instruction. Secondly, it investigates the factors that influence their beliefs.

\section{LITERATURE REVIEW}

Borg [2] proposed a definition for teachers' beliefs as "used to refer to teachers' pedagogic belief or those beliefs of relevance to an individual's teaching". This definition provides us with a clear understanding of teachers' beliefs. The term teacher's belief in this paper refers to opinions, attitudes and theories the pre-service teachers hold about grammar teaching. Gilakjani and Sabouri[3] claim that teachers' beliefs affect what they accomplish in their classroom. They guide teachers to adopt their teaching strategies for coping with teaching challenges and shape language learners' language ability. Teachers' beliefs on teaching grammar are closely related to their class effect. Thus, investigating pre-service teachers' beliefs on teaching grammar instruction is crucial in that each teacher candidate has his or her own beliefs.
In recent years, the research on teachers' beliefs on teaching grammar instruction has aroused great interest and attention. Liviero [4] reveals various interpretations of the concept of grammar and grammar teaching. Their prior knowledge and beliefs have an effective role in developing them as teachers. Furthermore, Shatat [5] shows that teachers' beliefs were inconsistent with their classroom practices due to factors such as time constraints, textbooks, and students' needs and proficiency levels. Liu and Rutledge [6] indicate that their beliefs are influenced by specific social and cultural contexts in which they are involved.

Because of pre-service teachers' varied experiences, their teaching beliefs are affected and challenged from all aspects. Only by investigating and analyzing their beliefs can we accurately explore the potential reasons for their beliefs about grammar teaching, thus providing inspiration and implication to grammar and language teaching.

\section{RESEARCH METHODOLOGY}

The chief goal of this research is to find out pre-service English teachers' beliefs about grammar instruction and factors that affect their beliefs. Specifically, this paper addresses the following questions:

(1) What beliefs do pre-service English teachers have on teaching grammar instruction?

(2) What factors influence their beliefs?

Participants of the study consist of seventy-eight pre-service English teachers from one of the normal universities in Hubei province. They range in age from 19 to 23 , including 12 male students and 66 female students. Basic information about them is available in Table 1. 
Table 1. Background of Participants

\begin{tabular}{|c|c|c|c|}
\hline \multicolumn{2}{|c|}{$\begin{array}{c}\text { Information of } \\
\text { Pre-service Teachers }\end{array}$} & Data & Percentage \\
\hline \multirow{2}{*}{ Gender } & Male & 12 & $15.38 \%$ \\
\cline { 2 - 4 } & Female & 66 & $84.62 \%$ \\
\hline \multirow{2}{*}{ Grade } & Junior & 29 & $37.18 \%$ \\
\cline { 2 - 4 } & Senior & 49 & $62.82 \%$ \\
\hline
\end{tabular}

This study adopts a mixed mode approach to research. The first part starts with a survey in which quantitative data are first collected through questionnaires. The respondents are asked to assess their beliefs about grammar teaching on a five-point Likert scale. The survey is aimed to obtain generalizable conclusions about the beliefs of these pre-service teachers. The questionnaires are based on the widely used questionnaires of Alghanmi and Shukri [7] and Shatat [5]. In the second part, seventeen pre-service teachers are randomly chosen and interviewed with the purpose of finding out detailed information about the reasons which influence their teaching beliefs and practices about grammar teaching. Questions asked include the participants' general background, their English learning experience, etc. All of the interviews are audiotaped, and later transcribed.

\section{RESULTS AND DISCUSSION}

The focus of grammar teaching aims had shifted from formal correctness towards communicative effectiveness. Broadly speaking, in teaching grammar, four approaches can be applied in English classrooms: Inductive, Deductive, Focus on Form and Focus on Meaning instructional approaches [5]. The following statements tend to explore pre-service teachers' beliefs regarding different teaching grammar instructions.

\subsection{Focus on Form Instruction}

Focus on Form Instruction refers to an approach to teaching grammar aiming at providing the learners with accuracy competence. Pre-service teachers' opinions about suitable approaches to grammar are based upon their students' needs and expectations. Table 2 below shows the pre-service teachers' form-focus beliefs in detail.

Table 2. Beliefs Regarding Focus on Form

\begin{tabular}{|l|l|l|l|l|l|}
\hline \multicolumn{1}{|c|}{ Statements } & $\begin{array}{l}\text { Strongly } \\
\text { disagree }\end{array}$ & Disagree & Unsure & Agree & Strongly agree \\
\hline $\begin{array}{l}\text { 1. Accuracy is more important than } \\
\text { appropriateness. }\end{array}$ & $3.85 \%$ & $50 \%$ & $15.38 \%$ & $28.21 \%$ & $2.56 \%$ \\
\hline $\begin{array}{l}\text { 2. Learners' mistakes should always be } \\
\text { corrected immediately. }\end{array}$ & $15.38 \%$ & $43.59 \%$ & $8.97 \%$ & $28.21 \%$ & $3.85 \%$ \\
\hline $\begin{array}{l}\text { 3. Students should be encouraged to use } \\
\text { the right form from the beginning. }\end{array}$ & $1.28 \%$ & $6.42 \%$ & $10.26 \%$ & $71.79 \%$ & $10.26 \%$ \\
\hline 4. Guarantee form accuracy is vital. & $1.28 \%$ & $5.13 \%$ & $17.95 \%$ & $67.97 \%$ & $7.69 \%$ \\
\hline 5. Teachers should focus on form. & $16.67 \%$ & $43.59 \%$ & $17.95 \%$ & $20.51 \%$ & $1.28 \%$ \\
\hline 6. All grammar errors should be corrected. & $3.85 \%$ & $50 \%$ & $14.1 \%$ & $30.77 \%$ & 1.285 \\
\hline
\end{tabular}

Most pre-service teachers have paradoxical attitudes: over $50 \%$ (statement 1 ) of the respondents think accuracy is less important than appropriateness and teachers should not correct students' errors directly and immediately (statement 2) and about $60 \%$ think we should focus more on meaning rather than form (statement 5), while more than $80 \%$ of the respondents think students should be encouraged to use the right form (statement 3 ) and over $70 \%$ of them think the linguistic form is a primary goal in language teaching (statement 4). Statement 6 reveals that around half of them do not believe in the effectiveness of explicit teaching when teaching grammar.

Some pre-service teachers favor form-focus grammar instruction such as drilling, memorizing grammar rules because of the pressure of examination-oriented education. Participant A, for example, says she takes a positive attitude towards this method: "although the Ministry of Education promotes quality education, examination-oriented education still has the priority. Under the pressure from society, school and parents, I have to pay attention to linguistic form. Otherwise, I will not achieve decent grades during tests. And I think we should be flexible in choosing different approaches since they all have their own merits. In other words, different methods should be cooperated and implemented together to facilitate the effect of grammar teaching."

\subsection{Focus on Meaning Instruction}

Focus on Meaning Instruction is an approach which is mainly concerned with communicative purposes but with little attention to the forms. Table 3 below shows their attitudes towards meaning-focus grammar instruction in detail. The majority of pre-service teachers believe in the importance of learning grammar through exposure to the language in a natural context. 
Table 3. Beliefs Regarding Focus on Meaning

\begin{tabular}{|l|c|c|c|c|c|}
\hline \multicolumn{1}{|c|}{ Statements } & $\begin{array}{l}\text { Strongly } \\
\text { disagree }\end{array}$ & Disagree & Unsure & Agree & Strongly agree \\
\hline $\begin{array}{l}\text { 7. You do not need to speak grammatically in } \\
\text { order to communicate well. }\end{array}$ & $1.28 \%$ & $5.13 \%$ & $5.13 \%$ & $62.82 \%$ & $25.64 \%$ \\
\hline 8. Errors can be tolerant. & $1.28 \%$ & $21.79 \%$ & $12.82 \%$ & $55.13 \%$ & $8.97 \%$ \\
\hline $\begin{array}{l}\text { 9. Teachers should concentrate on integrated } \\
\text { learning. }\end{array}$ & $0 \%$ & $0 \%$ & $2.56 \%$ & $70.51 \%$ & $26.92 \%$ \\
\hline $\begin{array}{l}\text { 10. Learners learn grammar best through } \\
\text { exposure to language in natural contexts. }\end{array}$ & $0 \%$ & $0 \%$ & $2.6 \%$ & $36.4 \%$ & $61 \%$ \\
\hline $\begin{array}{l}\text { 11. Practice of grammar must always be within } \\
\text { a communicative context }\end{array}$ & $0 \%$ & $1.2 \%$ & $3.8 \%$ & $60 \%$ & $35 \%$ \\
\hline
\end{tabular}

We can see that most pre-service teachers hold tolerant attitudes towards grammar errors and they encourage students to express their thoughts in English even if they do not speak grammatically (statements 7 and 8). Nearly $70 \%$ of them think teachers should pay attention to the comprehensive understanding of the text (statement 9). The majority of them claim that it is wise to learn grammar in natural contexts (statements10 and 11).

Participant B claims: "task-based language teaching advocates focusing on meaning in the process of teaching. Any words or sentences out of context are meaningless. So, I tell myself, when I become an English teacher, I should focus on meaning. However, the pressure of examinations forces us to concentrate on form. It is difficult for me to deal with that dilemma."

From the interview, over $85 \%$ of teachers agree that appropriateness is more important than accuracy in oral English. While in writing, especially in the examination, accuracy is more important. So, it is the examination-oriented education that influences their attitudes towards the importance of appropriateness and accuracy. Therefore, form and meaning may be two sides of a coin. It is wise for pre-service teachers to make a balance between them, thus providing the learners with both accuracy and fluency competence.

\subsection{Deductive Approach}

The deductive (top-down) grammar teaching approach works from the general to the specific. That is, rules or theories are presented first and then their applications are treated. This is based on presentation, explanation and practice. Firstly, the role of teacher is to describe in detail how the new structure is formed and in what type of context it can be used. Secondly, the learners are provided with examples illustrating the new structure. Finally, they are asked to apply the rules to new sentence

Table 4. Beliefs Regarding Deductive Approach

\begin{tabular}{|l|c|c|c|c|c|}
\hline \multicolumn{1}{|c|}{ Statements } & $\begin{array}{l}\text { Strongly } \\
\text { disagree }\end{array}$ & Disagree & Unsure & Agree & Strongly agree \\
\hline 11. Simple rules should be taught first. & $0 \%$ & $2.56 \%$ & $3.85 \%$ & $75.64 \%$ & $17.95 \%$ \\
\hline $\begin{array}{l}\text { 12. Teachers should inform students about rules } \\
\text { and then let them do exercises. }\end{array}$ & $12.82 \%$ & $51.28 \%$ & $24.36 \%$ & $10.26 \%$ & $1.28 \%$ \\
\hline $\begin{array}{l}\text { 13. What students learn should within their } \\
\text { ability. }\end{array}$ & $7.69 \%$ & $58.97 \%$ & $20.51 \%$ & $12.82 \%$ & $0 \%$ \\
\hline 14. Teachers should always explain rules. & $5.13 \%$ & $56.41 \%$ & $17.95 \%$ & $20.51 \%$ & $0 \%$ \\
\hline $\begin{array}{l}\text { 15. Direct explanation of grammar is more secure } \\
\text { to ensure students' understanding. }\end{array}$ & $23 \%$ & $30 \%$ & $20 \%$ & $21.9 \%$ & $5.1 \%$ \\
\hline
\end{tabular}

The results show that, on the one hand, they argue students should not learn complex grammar rules until they master simple rules (statement 11). On the other hand, they have an objection to statement 13: learning material should not be beyond their ability, which means that they agree with the opinion that students should be encouraged to challenge demanding tasks. Most of them set their faces against the deductive method: only $20.51 \%$ of them think teachers should always explain the grammar rules to students (statement 14). Furthermore, over $60 \%$ of them disagree that teachers should inform students about rules and then let them do related exercises (statement14). Therefore, most of them think it is inappropriate to explain grammar rules directly and explicitly (statement 15 ).

During the interview, almost $75 \%$ of respondents argue that the use of the deductive method has declined dramatically since the inductive method is the basic way to arrange grammar in the textbooks. Participant $\mathrm{C}$ argues: "I do not like the deductive approach, which seems that we are training to be grammar experts in the future. During the whole class, we actually do not have much room to interact with each other or draw conclusions by ourselves. In high school, my English teacher always taught us by giving rules directly, and then she asked us to memorize them. I think it is better to combine different approaches. Otherwise, it will frustrate the students learning initiatives." 


\subsection{Inductive Approach}

The inductive (bottom-up) grammar teaching approach means that we observe a number of specific instances and from which we deduce a general principle. Teachers facilitate learners to notice and find out what the rule is and to arrive at some generalization of the rule governing the material presented through strategies. Therefore, the learners will be fully motivated, and they will become an active participant instead of being simply passive recipients.

Table 5. Beliefs Regarding Deductive Approach

\begin{tabular}{|l|c|c|c|c|c|}
\hline \multicolumn{1}{|c|}{ Statements } & Strongly disagree & Disagree & Not sure & Agree & $\begin{array}{l}\text { Strongly } \\
\text { agree }\end{array}$ \\
\hline $\begin{array}{l}\text { 16. Teachers should begin teaching a new } \\
\text { grammar point by giving examples }\end{array}$ & $2.56 \%$ & $5.13 \%$ & $8.97 \%$ & $71.79 \%$ & $11.54 \%$ \\
\hline 17. Teachers should explain rules in Chinese. & $3.85 \%$ & $28.13 \%$ & $20.5 \%$ & $44.87 \%$ & $2.56 \%$ \\
\hline 18. Students work out rules by themselves. & $1.28 \%$ & $5.13 \%$ & $6.41 \%$ & $75.64 \%$ & $11.54 \%$ \\
\hline 19. Interpretation rules should be avoided. & $5.22 \%$ & $39.74 \%$ & $21.7 \%$ & $29.49 \%$ & $3.85 \%$ \\
\hline $\begin{array}{l}\text { 20. The role of teachers is to help learners } \\
\text { induce the grammar rules by themselves. }\end{array}$ & $0 \%$ & $0 \%$ & $1.28 \%$ & $69.23 \%$ & $29.49 \%$ \\
\hline
\end{tabular}

More than $80 \%$ of the pre-service teachers claim that while teaching grammar teachers should give examples first (statement 16). So, students can find and conclude underlying rules by themselves, which is beneficial to their learning (statement 18 and 20). As for whether teachers should explain rules in Chinese, they hold rather different opinions: slightly more people argue that it is necessary to interpret rules in Chinese (statement 17). Participant D says: "I am in favor of the deductive approach since students can draw conclusions by themselves through their own thinking. What is more, students can have more opportunities to be deeply and fully engaged in the classroom."

So, which method is more suitable for grammar teaching: the deductive method or inductive method? Grammar teaching needs to consider not only linguistic factors but also learners' psychological factors and social factors. To sum up, table 5 above shows that most pre-service teachers prefer to teach grammar implicitly and they believe that grammar instruction is more effective when students work out the rules by themselves after being exposed to examples.

\subsection{Beliefs about Using Grammatical Terminology}

Table 6 displays pre-service teachers' beliefs concerning the role of grammatical terminology. The results show that $76.92 \%$ of the surveyed pre-service English teachers agree that terms should be used to explain rules. (statement 21); $88.46 \%$ of the respondent agree that students should use common grammar rules while discussing grammar (statement 22); and $92.31 \%$ of them argue that students should understand common English grammar terms (statement 23). Therefore, pre-service teachers' preference for grammar terms is explicit: an overwhelming majority of them choose to explain and use grammar terms.

Table 6. Beliefs Regarding Grammatical Terminology Instruction

\begin{tabular}{|l|c|c|c|l|c|}
\hline \multicolumn{1}{|c|}{ Statements } & Strongly disagree & Disagree & Unsure & Agree & Strongly agree \\
\hline $\begin{array}{l}\text { 21. Terms should be used to explain } \\
\text { rules. }\end{array}$ & $2.56 \%$ & $8.97 \%$ & $11.54 \%$ & $69.23 \%$ & $7.69 \%$ \\
\hline $\begin{array}{l}\text { 22. Students should use grammatical } \\
\text { rules while discussing grammar. }\end{array}$ & $0 \%$ & $2.56 \%$ & $8.97 \%$ & $79.49 \%$ & $8.97 \%$ \\
\hline 23. Students should understand terms. & $0 \%$ & $0 \%$ & $7.69 \%$ & $73.08 \%$ & $19.23 \%$ \\
\hline
\end{tabular}

The interview results also conform that pre-service teachers are fully aware of the importance of grammar terms. Participant E claims, "knowing some basic grammatical terms is necessary since they provide us with a better understanding of our learning materials. Some professional examinations require English terminology such as Test for English Majors, Grade Four." The majority of pre-service teachers agree that it is necessary to familiarize the students with grammatical terminology in order to pass the examination.

\section{CONCLUSION}

This paper aims at identifying pre-service English teachers' beliefs on teaching grammar instruction as well as factors that influence their beliefs. As for the first question: the participants seem to hold similar beliefs. All of them believe in the importance of teaching grammar although they have multifaceted beliefs about various approaches. They, in general, have a preference for the 
meaning-focused-instruction and inductive approach. Nevertheless, the pre-service teachers tend to be flexible in their choice of grammar approaches as they see each type of practice has its own advantages. Their choice depends on the specific grammar topics as well as learners' background knowledge.

As for the second question, the majority of participants agree that their grammar learning experience, teaching experience, and examination system have a huge impact on their beliefs and practices. In addition to students' needs, motivation and aptitude. According to Andrews [8], their beliefs are influenced not only by the macro-culture of the society (syllabus, books, examination system, expectations of parents, their learning styles and learning experiences) but also by the micro-culture of their particular institution. In sum, it's important to take pre-service English teachers' beliefs into consideration towards grammar teaching since they are likely to hold their own beliefs in classroom. The paper provides us with a clear picture of what kind of grammar teaching takes place in the classroom. Therefore, these findings have implications for pre-service teachers' training, which can help educators to better design pre-service teachers' training programs.

\section{ACKNOWLEDGMENT}

This research was supported by "the Fundamental Research Funds for the Central Universities (WUT: 2020VI035)".

\section{REFERENCES}

[1] D. Busch, "Pre-service teacher beliefs about language learning: the second language acquisition course as an agent for change," Language Teaching, 2010, vol. 14(3) 318-337. DOI:

$10.1177 / 1362168810365239$
[2] M. Borg, "Teachers' beliefs," Journal of English Language Teaching, 2001, vol. 55(2), 186-188. DOI: org/10.1093/elt/55.2.186

[3] A. P. Gilakjani and N. B. Sabouri, “Teachers' beliefs in English language teaching and learning: a review of the literature," English Language Teaching, 2017, vol. 10, No. 4. DOI: 10.5539/elt. v10n4p78

[4] S. Liviero, "Grammar teaching in secondary school foreign language learning in England: teachers reported beliefs and observed practices," The Language Learning Journal, 2017, vol. 45(1):1-25. DOI: 10.1080/09571736.2016.1263677.

[5] Z. Y.M. Shatat, "Grammar teaching in Sharjah preparatory (Cycle 2) schools teachers' beliefs and classroom practices[D],"2011, Ph.D. Dissertation. Dubai: The British University in Dubai.

[6] J. Liu and D. Rutledge, "Pre-service teachers' beliefs about language learning inventory (BALLI) on bilingualism: getting insights to developing knowledge," English Language Teaching, 2020, vol. 13, No. 9. DOI: 10.5539/elt. v13n9p30

[7] B. Alghanmi and N. Shukri, "The relationship between teachers' beliefs of grammar instruction and classroom practices in the Saudi Context," English Language Teaching, 2016, vol. 9, No. 7 DOI: 10.5539/elt. v9n7p70.

[8] S. Andrews, "Just like instant noodles: L2 teachers and their beliefs about grammar pedagogy," Teachers and Teaching: theory and practice, 2010, vol. 9:4, 351-375.DOI: 10.1080/1354060032000097253 